\title{
MECHANICAL HARVESTING OF CANOLA CROP UNDER DIFFERENT PLANTING METHODS
}

\author{
Al-Gezawe, A. A.I.* andK. I. W. Ahmed**
}

\section{ABSTRACT}

Field experiments were carried out to select the optimum mechanical harvesting and threshing methodof canola crop (Brassica napus L.) under different planting methods. The performance of reciprocating mower and thresherwas evaluated comparing with combine harvesteras a function of change in forward speed $(1.9,2.5,3.1$ and $4.2 \mathrm{~km} / \mathrm{h})$, grain moisture content $(10.4,14.5,17.8$ and 21.3\%) under different planting methods of manual, seed drill and pneumatic planterin terms of field capacity, field efficiency, total losses, power, energy and cost requirements. The experimental results reveal that total grain losses, energy and cost requirementswere in the optimum region under the following recommended conditions:

- Harvesting canola crop by using combineharvester in order to minimize the total losses, energy and cost requirements.

- Optimum forward speed for harvesting canola crop is about $3.1 \mathrm{~km} / \mathrm{h}$, so as to obtain minimum cost requirements.

- Harvesting canola crop at an average grain moisture content of $14.5 \%$ to achievethe least losses as possible.

- Planting canola crop by pneumatic planter as the best method to ensureminimal grain consumption and optimal product yield.

\section{INTRODUCTION}

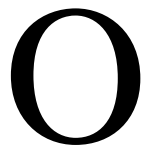
il crops are considered one of the important sources of nutrition for millions of people all over the world. Canola (Brassica napus, L.) is a name applied to edible oilseed rape andconsidered as one of the most important oil crops in the world because its seeds contain about $40 \%$ oil and $23 \%$ protein. Canola is thought to have beneficial effects on soil structure. Where there is no subsoil hardpan, the large taproot provides channels that improve the rate of water infiltrationand may provide access for the roots of following crops into the subsoil.

\footnotetext{
* Researcher of Agric. Res. Inst., Agric. Res Centet, Dokki, Egypt. **Lecturer of Agric. Eng. Dep., Fac. Agric. Zagazig Univ., Egypt.
} 
The extensive fine root system in the surface also improves surface soil structure, creating more stable soil aggregates than those formed under cereals, and increasing infiltration rate. These effects are probably responsible for the common observation by farmers that canola leaves the soil more friable and easy to work.

The sowing and harvest times of canola are usually earlier than wheat, which spreads the time for using existing machinery. Timely harvest of canola is critical to prevent shattering. Shattering can account for significant crop losses, therefore harvesting must not be delayed. Pods and grains color is more important than overall color of the filed in determining plant maturity.The factors that control the performance of harvesting machines can be divided into two sections: machine and plant. Machine variables include forward speed, peripheral speed of combineharvester cutter baror reciprocating mower devices and feeding rate. Plant variables are considered critical factors such as variety, moisture content and degree of maturity. These mentioned factors affect directly on the crop losses, energy and cost requirements.El-Haddad $\boldsymbol{e t}$ al. (1995) reported that combine harvester gave the lowest cost of about 229.0 L.E/fed in comparison with 283.4 L.E/fed for mounted mower and 300.0 L.E/fed for manual sickle system.Lotfyet al. (2002) evaluated two different methods for harvesting and threshing winter rapeseed crop in North Delta of Egypt. The first method by using combine harvester (Case-International 1620) was evaluated at different parameters such as: forward speed, drum speed, drum concave clearance at different moisture content of grains. The second method was by the traditional method (manual harvesting and mechanical threshing by using local threshing machine). The results revealed that by using combine harvester, the minimum rate of grain losses was $6.4 \%$ and maximum performance efficiency was $93.6 \%$ at forward speed of $1.8 \mathrm{~km} / \mathrm{h}$; drum speed of $28 \mathrm{~m} / \mathrm{s}$, drum concave clearance of $8 \mathrm{~mm}$ and grains moisture content of $15.3 \%$. While, by using traditional method, the minimum rate of grain losses was $11.6 \%$ and maximum efficiency of threshing machine performance was $88.4 \%$ at drum speed of $27.5 \mathrm{~m} / \mathrm{s}$ and grains moisture content of $15.3 \%$. Energy requirement for the second method was equal 2.5 to 3.0 times of the first method. Total harvesting cost in the second method was equal to 
1.7 times of the first method. So, the combine harvester is considered the proper method for harvesting winter rapeseed crop.Imaraet al. (2003) found thatthe total grain losses increased by increasing the combine forward speed. The total grain losses of indirect harvesting method (using mower and threshing machine) increased about 2.5 times of that of total grain losses of direct harvesting (using combine harvester).Maniet al. (2012) mentioned that effective mechanical harvesting time for decreasing harvesting loss of winter oilseed rape has been becoming a critical factor. An elite cultivar Zhongshuang 11 (Brassica napus L.) was employed in two rounds of field experiments from 2009 to 2011. Seeds were sown with machine, three combine harvesting times namely combine harvesting $\mathrm{A}, \mathrm{B}$, and $\mathrm{C}(\mathrm{CHA}, \mathrm{CHB}$, and $\mathrm{CHC})$ were designed and manual harvesting $(\mathrm{MH})$ as control was performed at maturity. The harvesting treatments were determined according to color of pod and grains in the field. Grain yield loss and quality in different treatments were evaluated. Results showed that the highest yield appeared in CHB, which was significantly higher than that in $\mathrm{MH}$. Furthermore, harvesting loss in $\mathrm{CHB}$ was $50 \%$ that in $\mathrm{MH}$. Seed oil content and chlorophyll exhibited no obvious difference between $\mathrm{CHB}$ and $\mathrm{MH}$. Economic profit analysis demonstrated that mechanical sowing/combine harvesting (MS/CH) showed an input/output ratio of 1:1.6, and it was 1:1.2 in mechanical sowing/manual harvesting (MS/MH). Labor-cost accounted for more than $70 \%$ of the total cost in $\mathrm{MS} / \mathrm{MH}$, which led to low profitability to a great extent.

\section{So, the objectives of this work are to:}

1. Select the best mechanized harvesting methods for canola crop in order to minimize grain losses that occur in the harvesting operation.

2. Optimize some different operating parameters affecting the performance of the mechanical harvesting and threshingof canola crop.

3. Determine the suitable planting method for canola crop to maximize crop yield.

4. Evaluate the used harvestingand threshing systems from the economic point of view. 


\section{MATERIALS AND METHODS}

Field experiments were carried out on clay soilthrough agricultural season of 2012/2013at Kafr El-Hamamfarm, Sharkia Governorate, Egypt to select the optimum harvesting and threshing methods of canola crop under different planting methods in order to reduce total losses, energy and costrequirements. The mechanical analysis of the used experimental soil is $48.70 \%$ clay, $34.55 \%$ silt and $16.75 \%$ sand.

\section{MATERIALS}

\section{Crop}

The used canola cropwith an average of $165 \mathrm{~cm}$ length, 6 branches per plant and $1.80 \mathrm{~cm}$ stem diameters with a plant population of 110 plant $/ \mathrm{m}^{2}$ under traditional methodwas harvested under all tests.

\section{Machinery and equipment}

The following machines were used in carrying out this investigation:

2.1. Combine harvester (Kubota):CA-385 EG Japan, Turbo diesel, four stroke, water cooled, 3 cylinders,engine power $35.33 \mathrm{~kW}$ (48hp), at 2800 rpm, cutting width $1400 \mathrm{~mm}$,threshing drum (dia. $\times$ length) $420 \times 710 \mathrm{~mm}$, threshing drum rotating speed $520 \mathrm{rpm}$, overall length $4063 \mathrm{~mm}$, overall width $1904 \mathrm{~mm}$, overall height $2000 \mathrm{~mm}$ and mass $1979 \mathrm{~kg}$.

2.2. Tractor Universal $650 \mathrm{M}$ : Tractor Universal $650 \mathrm{M}(2 \mathrm{WD})$, made in Romania, four stroke, Diesel with direct injection, engine power 55.15 $\mathrm{kW}(75 \mathrm{hp}$ ), engine rated speed $1440 \mathrm{rpm}$ and mass $3820 \mathrm{~kg}$.

2.3. Tractor Kubota M8030-DT:Tractor Kubota M 8030-DT (4WD), made in Japan, four stroke, Diesel with direct injection, engine power $22.08 \mathrm{~kW}$ (30 hp), engine rated speed $2800 \mathrm{rpm}$ and mass $1450 \mathrm{~kg}$.

2.4. Reciprocating mower: Busatis M. 1102, made in Germany, rear mounted cutter-bar mower, source of power from P.T.O. Tractor, cutting width $1600 \mathrm{~mm}$, mass $190 \mathrm{~kg}$ and control hydraulic.

2.5. Thresher: Turkish thresher, El-shams, Egypt, Spike tooth drum, diameter of drum $630 \mathrm{~mm}$, length of drum $1200 \mathrm{~mm}, 11$ fingers per row, knife length $300 \mathrm{~mm}$, concave length $120 \mathrm{~mm}$, concave clearance $\quad 28$ $\mathrm{mm}$, centrifugal blower, overall length $4000 \mathrm{~cm}$, overall width $2300 \mathrm{~cm}$ and overall height $2400 \mathrm{~cm}$.

\section{METHODS}

The harvested experimental area of canola crop was about 3 feddans. 
They divided into three equal plots (1feddan each). Every plot has dimensions of $(105 \times 40 \mathrm{~m})$. The first plot was cultivated manually, the second plot was cultivated using the seed drill, while the third plot was cultivated using the pneumatic planter. Each plot was divided into two subplots ( 0.5 feddan each).

Two experimental groups namely A and B were carried out in each subplot:

A.The first group of tests was carriedout underreciprocating mounted mower and threshing machine.

B.The second group of tests was conducted by combine harvester.

Manual planting was carried out with a seed rate of $3 \mathrm{~kg} / \mathrm{fed}$, while planting by seed drill was conducted at $40 \mathrm{~cm}$ distance between rows with a seed rate of $2.5 \mathrm{~kg} / \mathrm{fed}$. Planting by pneumatic planter was deduced at 60 $\mathrm{cm}$ distance between rows and $5 \mathrm{~cm}$ between seeds in the same row with a seed rate of $2 \mathrm{~kg} / \mathrm{fed}$.

The reciprocating mounted mower was operated by tractor Kubota with $30 \mathrm{hp}$, while threshing machine was operated by Tractor Universal (650M) with $75 \mathrm{hp}$. These groups were rununder four grain moisture contents of $10.4,14.5,17.8$ and $21.3 \%$ and four forward speeds of 1.9, 2.5, 3.1 and $4.2 \mathrm{~km} / \mathrm{h}$.

Grain moisture content was determined on dry basic with the standard oven method at $105^{\circ} \mathrm{C}$ for $24 \mathrm{~h}$. in laboratory at faculty of Agriculture, ZagazigUniversity.

\section{- Measurements}

Evaluation of treatment Acomparing with treatment B was carried out taking into consideration the following indicators:

\section{- Theoretical field capacity}

The theoretical field capacity is the rate of the field coverage that would be obtained if the machine was performance its function $100 \%$ of the time at the rated forward speed and always covered $100 \%$ of its rated width (Kepneret al. 1978). Thus, it calculated as:

$$
T_{\text {f.c. }}=\left(W_{m} x F_{s}\right) / 4.2
$$

Where: $T_{f . c}$ : Theoretical field capacity, fed/h

$W_{m}$ : Width of the machine, $\mathrm{m}$

$F_{s}:$ Forward speed, $\mathrm{km} / \mathrm{h}$ 


\section{- Actual field capacity}

Actual field capacity was based upon the total effective operating time (Kepneret al. 1978). Thus, it calculated as:

$$
A_{\text {f.c. }}=1 / T_{t}
$$

Where: $A_{f . c .}:$ Actual field capacity, fed/h

$T_{t}$ : Actual total time in hours required per feddan, $\mathrm{h} / \mathrm{fed}$

\section{- Field efficiency}

The field efficiency was calculated by using the following formula:

$$
\eta_{f}=\left(A_{f . c .} / T_{f . c .}\right) \times 100
$$

Where: $\eta_{f}$ : Field efficiency, $\% T_{\text {f.c.: }}$ Theoretical field capacity, fed/h

\section{- Total grain losses}

The percentage of total grain losses was calculated using the following equation:

Total grain losses $=($ Pre-cutting + Un-cutting + Operating + Threshing $)$ losses, $(\%)$

\section{- Fuel consumption}

Fuel consumption per unit time was determined by using a calibrated tank (Refilling method) to measure the volume of fuel consumed during the operation time.

\section{- Required power}

The required power was calculated using the following formula (Barger, et al. 1963).

$$
P=w f \times c . v . \times 427 \times \eta_{t h} \times \eta_{m} \times 1 /(1.36 \times 75)
$$

Where: $P$ : Required power, $\mathrm{kW} \quad w_{f}$ : Rate of fuel consumption, $\mathrm{kg} / \mathrm{s}$ c.v.: Calorific value of fuel, $\mathrm{kcal} / \mathrm{kg}$

(Average c.v. of solar fuel is $10000 \mathrm{kcal} / \mathrm{kg}$ )

427: Thermo - mechanical equivalent, kg.m / kcal

$\eta_{\mathrm{th}}$ : Thermal efficiency of the engine,

(Considered to be about $30 \%$ for diesel engine)

$\eta_{\mathrm{m}}$ : Mechanical efficiency of the engine, $83 \%$ for diesel engines.

\section{- Energy requirements}

Energy requirement was estimated according to fuel consumption by the following equation:

Energy requirements perfeddan $(\mathrm{kW} . \mathrm{h} / \mathrm{fed})=\frac{\text { Required power }(\mathrm{kW})}{\text { Actual field capacity }(\text { fed } / \mathrm{h})}$

Energy requirements per unit of production $(\mathrm{kW} \cdot \mathrm{h} / \mathrm{Mg})=\frac{\text { Energy requirements per feddan }(\mathrm{kW} \cdot \mathrm{h} / \mathrm{fed})}{\text { Crop yield }(\mathrm{Mg} / \mathrm{fed})}$ 
Energy requirements per unit of production were calculated once for combine harvesterand the otherfor reciprocating mower and thresher.

$E_{D}$ : Energy requirements per unit of production for operating combine harvester.

$$
\mathrm{E}_{\mathrm{I}}=\mathrm{E}_{\mathrm{h}}+\mathrm{E}_{\mathrm{th}}
$$

Where:

$\mathrm{E}_{\mathrm{I}}$ : Energy requirements per unit of production for operating reciprocating mower and thresher.

$E_{h}$ : Energy requirements per unit of production for operatingthe reciprocating mower.

$E_{\text {th }}$ : Energy requirements per unit of production for operating the threshing machine.

\section{- The operational cost}

The cost of mechanized operations was based on the initial cost of machine, interest on capital, cost fuel, oil consumed, cost of maintenance and wage of the operator according to the following formula of (Awady, 1978).

$$
c=P / h\left(\frac{1}{e}+\frac{i}{2}+t+r\right)+(0.9 h p \times f \times s)+\frac{W}{144}
$$

Where:c: Hourly cost, L.E./hP: Capital investment, L.E.

$h$ : Yearly operating hours. $e$ : Life expectancy of the machine, year

$i$ : Annual interest rate, $\% \quad t$ : Taxes and over heads ratio, $\%$

$r$ : Annual repairs and maintenance rate, $\%$

0.9: A factor including reasonable estimation of the oil consumption in additions to fuel

$h p$ : Horse power of engine, $\mathrm{hp}$

$f$ : Specific fuel consumption, $1 / \mathrm{hp} . \mathrm{h}$

$s$ : Fuel price, L.E./lW: Labor wage rate per month, L.E.

144: Reasonable estimation of monthly working hours

The operational cost can be determined by using the following formula:

$$
\begin{gathered}
\text { Operational } \cos t(\text { L.E./ fed })=\frac{\text { Hourly cost }(\text { L.E. } / \mathrm{h})}{\text { Actual field capacity }(\mathrm{fed} / \mathrm{h})} \\
\text { Operational } \cos t \text { per unit of production (L.E./ Mg })=\frac{\text { Oprational cost per feddan (L.E./ fed) }}{\text { Crop yield }(\mathrm{Mg} / \mathrm{fed})}
\end{gathered}
$$

The criterion cost was estimated by using the following formula of (Awady, et al. 1982)

Criterion cost $($ L.E./Mg) = Operational cost + Total grain losses cost 


\section{RESULTS AND DISCUSSION}

The acquired results will be discussed under the following heads:

\section{Field capacity and field efficiency}

Field capacity and field efficiency are very important parameters which should be taken into consideration through machine performance evaluation. Fig. (1) showed the effect of forward speed on field capacityand field efficiency of reciprocating mower and combine harvester under differentgrain moisture contents. Results indicated that increasing forward speed, increased field capacity and vice versa with field efficiency. Increasing forward speed from 1.9 to $4.2 \mathrm{~km} / \mathrm{h}$, increased field capacity from0.66 to $1.09,0.67$ to $1.10,0.65$ to 1.08 and 0.64 to1.07 $\mathrm{fed} / \mathrm{h}$ for reciprocating mower and from 0.57 to $0.94,0.58$ to $0.95,0.56$ to 0.93 and 0.55 to $0.92 \mathrm{fed} / \mathrm{hfor}$ combineharvester at grain moisture contents of $10.4,14.5,17.8$ and $21.3 \%$, respectively.While, the field efficiency decreased from 91.67 to $68.13,93.06$ to $68.75,90.28$ to 67.50 and 88.89 to $66.88 \%$ for reciprocating mower and from 90.48 to 67.14 , 92.06 to $67.86,88.89$ to 66.43 and 87.30 to $65.71 \%$ for combine harvester under the same speed conditions. The major reason for this reduction in field efficiency by increasing forward speed is due to the less theoretical time consumed in comparisonwith the other items of time losses.

\section{Total grain losses}

Total grain losses were affected by grain maturity, time of harvesting, field condition, forward speed and planting method. Results as shown in Fig. (2)explained that the highest value offorward speed, increased the total losses of treatment A and B under different planting methods. By decreasing forward speed from 3.1 to $1.9 \mathrm{~km} / \mathrm{h}$, the total losses of treatment A were increased from 5.13 to $5.31 \%, 4.94$ to $5.10 \%$ and 4.81 to $4.92 \%$ for manual, seed drill and pneumatic planter, respectively at grain moisture content of $14.5 \%$, however, the total grain losses of treatment B were increased from 2.70 to $3.14 \%, 2.47$ to $2.78 \%$ and from 2.30 to $2.51 \%$ under the same previous conditions.Increasing forward speed from 3.1 to $4.2 \mathrm{~km} / \mathrm{h}$, increased grain losses from $5.13 \%$ to 5.39 , $4.94 \%$ to $5.18 \%$ and $4.81 \%$ to $4.97 \%$ in treatment $\mathrm{A}$, as for the totallosses increased from $2.7 \%$ to $3.29 \%, 2.47 \%$ to $3.05 \%$ and from $2.30 \%$ 
Reciprocating mower

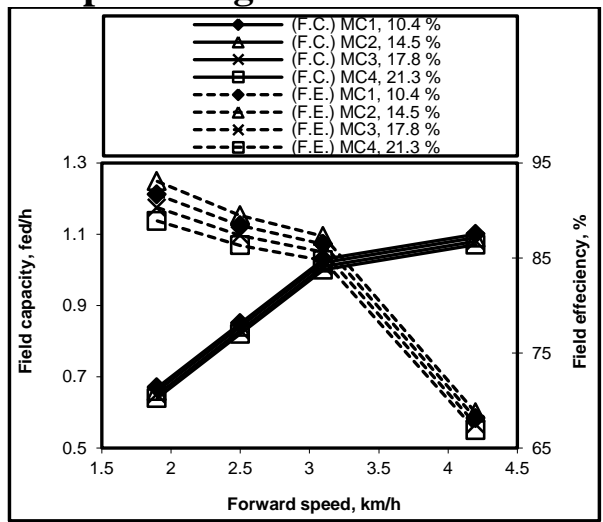

Combine harvester

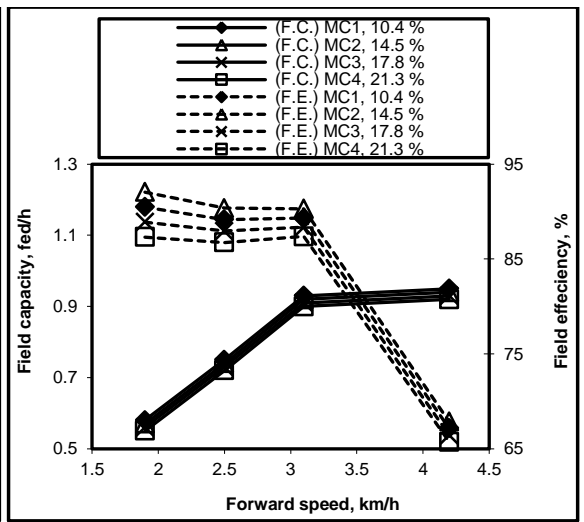

Fig. (1): Effect of forward speed on field capacity and field efficiency of reciprocating mower and combine harvester under different grain moisture contents

Treatment A

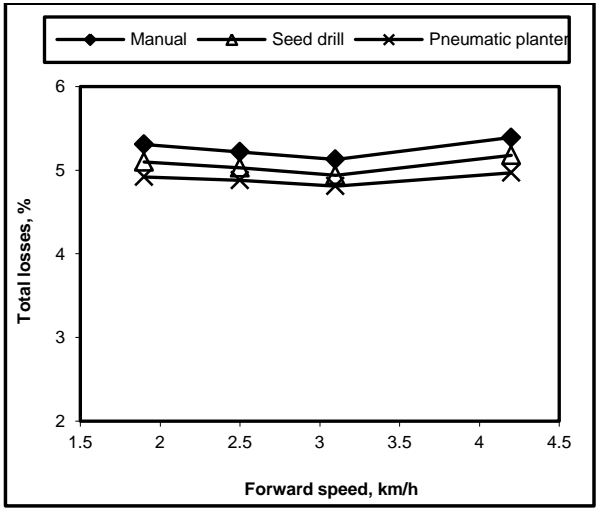

Treatment B

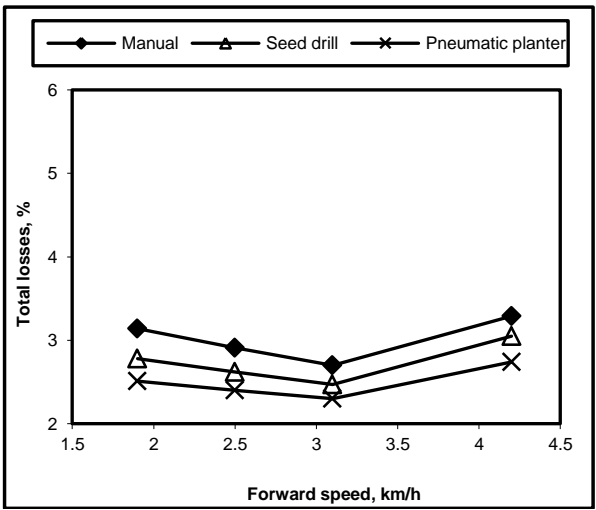

Fig. (2): Effect of forward speed on total losses of treatment $A$ and Bat grain moisture content of $14.5 \%$ under different planting methods

to $2.74 \%$ for treatment B under the same previous conditions. The increase in grain losses by increasing forward speed is attributed to the effect of plants forward deflections and high impact of the cutter bar with the plants. The lowest reduction in total losses was noticed under the use of pneumatic planter method for planting canola crop. This is may be attributed to good uniformity of distribution than other planting methods and no scramble between plants, resulting in reduction of total losses. As for the effect of grain moisturecontent on total losses as shown in Fig. (3), the results showed that the total grain losses were decreased by 
Treatment A

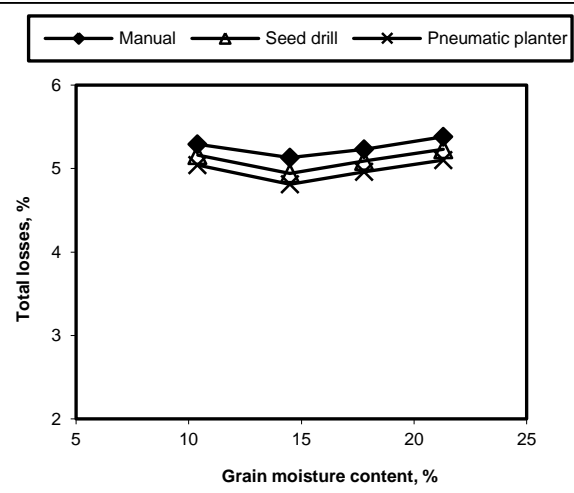

Treatment B

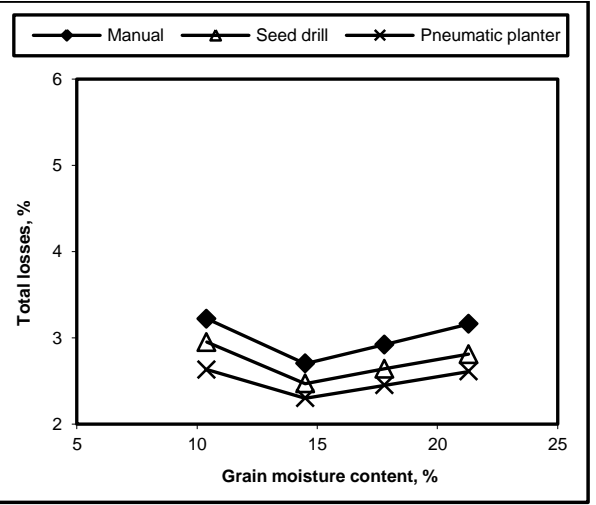

Fig. (3): Effect of grain moisture content on total losses of treatment $A$ and Bat forward speed of $3.1 \mathrm{~km} / \mathrm{h}$ under different planting methods

increasing grain moisture content up to $14.5 \%$ and then increased under different planting methods.Because at lower grain moisture content, more grains were available to leave the pods, so any action on the grains would separate them from pods and thus shattered by cutter bar speed. On the other hand, the increase in grain losses by increasing grain moisture content is due to the elastic conditions of high materials moisture content, swelled enough and not easily to be separated. At $14.5 \%$ grain moisture content, the percentage of total losses was $5.13 \%, 4.94 \%$ and $4.81 \%$ for treatment $\mathrm{A}$ and was $2.70 \%, 2.47 \%$ and $2.30 \%$ for treatment $\mathrm{B}$ under different planting methods of manual, seed drill and pneumatic planter and forward speed of $3.1 \mathrm{~km} / \mathrm{h}$. It was noticed from results that harvesting canola crop by combine harvester gave the least percentage of total grain losses than using reciprocating mower and thresher.

\section{Power and energy requirements}

The required power as well as the energy requirements are the best criterion for the suitable implement and very important from the design point of view. Figs. (4 and 5) showed the effect of forward speed and grain moisture content for manual, seed drill and pneumatic planter asdifferent planting methods on power and energy requirements. Data explained that by increasing forward speed, increased required power and vice versa was noticed with energy requirements. The required power of treatment A was increased from 26.33 to $35.32 \mathrm{~kW}, 25.89$ to $34.46 \mathrm{~kW}$ 
and 25.42 to $33.67 \mathrm{~kW}$ for manual, seed drill and pneumatic planter, respectively by increasing forward speed from 1.9 to $4.2 \mathrm{~km} / \mathrm{h}$ at grain moisture content of $14.5 \%$. While, required power was increased from 16.61 to $21.66 \mathrm{~kW}, 16.02$ to $21.14 \mathrm{~kW}$ and 15.38 to $20.77 \mathrm{~kW}$ for treatment B under the same former conditions. At $3.1 \mathrm{~km} / \mathrm{h}$ forward speed, energy requirements per unit of production were $36.56,35.90$ and $34.97 \mathrm{~kW} . \mathrm{h} / \mathrm{Mg}$ for treatment A while, $15.64,14.38$ and $12.67 \mathrm{~kW} . \mathrm{h} / \mathrm{Mg}$ for treatment $\mathrm{B}$ at $14.5 \%$ moisture content under different planting methods of manual, seed drill and pneumatic planter,respectively. The increase in power by increasing forward speed was attributed to excessive load of plants on the cutter bar and the high impact of cutter bar with plants, thereby increasing the friction resistance. While, the decrease in the energy requirements by increasing forward speed was attributed to high values of field capacity at higher forward speed up to $3.1 \mathrm{~km} / \mathrm{h}$. any further, increase in forward speed from 3.1 to $4.2 \mathrm{~km} / \mathrm{h}$, energy requirements will increase. Because the rate of increase in the required power was more than the increase in the field capacity at forward speed of $4.2 \mathrm{~km} / \mathrm{h}$, consequently energy requirements increased at $4.2 \mathrm{~km} / \mathrm{h}$. It was noticed that the highest power and energy requirements were recorded through manual method, this may be attributed to non-uniformity of planting distribution and thereby excessive load and impact of plants on cutter bar, resulting in more power and energy than other methods. Treatment B consumed less power andenergy thananother method, because the combine harvester carried out many operations asharvesting and threshing in one pass at the same time, thereby reduced the consumed time, power and energy requirements. Concerning the effect of grain moisture content on power and energy requirements, the obtained data revealed that by increasing grain moisture content from 10.4 to $21.3 \%$, the required power increased by $51.52,53.41$ and $52.68 \%$ for treatment $\mathrm{A}$ and $4.20,3.31$ and $3.73 \%$ for treatment Bat forward speed of $3.1 \mathrm{~km} / \mathrm{h}$ under manual, seed drill and pneumatic planter, in that order. While, the least energy requirements was obtainedat $14.5 \%$ moisture content, this may be attributed to the highest field capacity at this moisture content. 
Treatment A

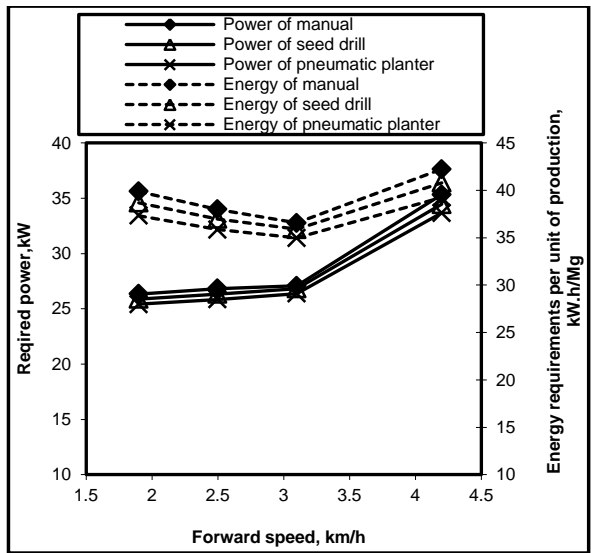

Treatment B

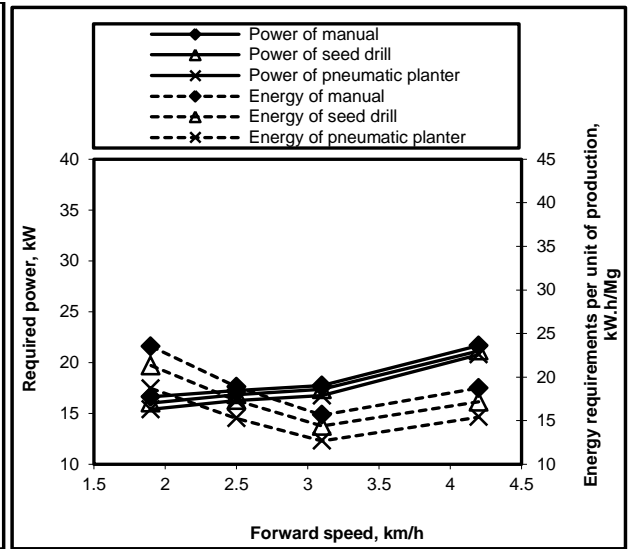

Fig. (4): Effect of forward speed on power and energy requirements of treatment A and Bat grain moisture content of $14.5 \%$ under different planting methods

Treatment A

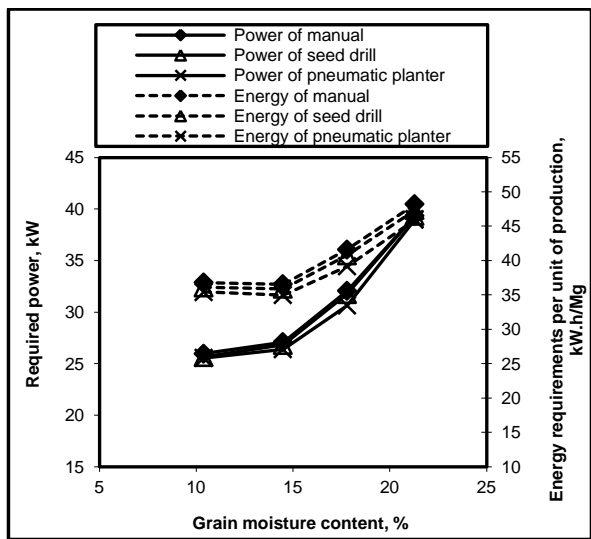

Treatment B

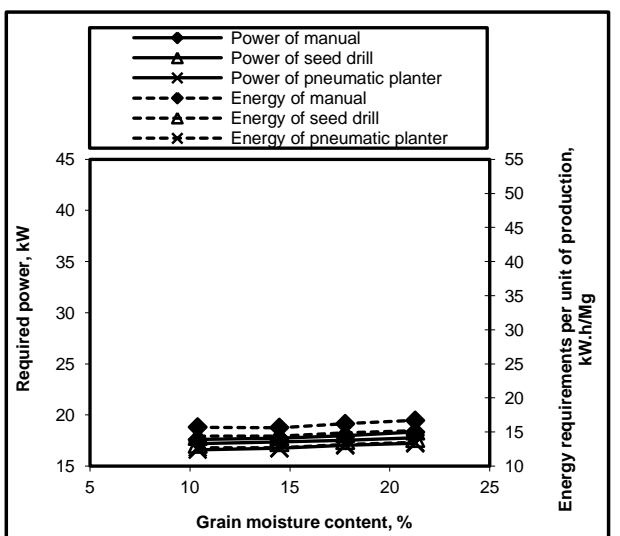

Fig. (5): Effect of grain moisture content on power and energy requirements of treatment $A$ and $B$ at forward speed of 3.1 $\mathrm{km} / \mathrm{h}$ under different planting methods

\section{Operational and criterion cost}

Total costs of performing a field operation include charges of the machine, the utilized power and labor.The criterion cost was used as an important indicator for selecting the optimum harvesting system of canola cop. It was based on harvesting time, losses, fuel and operating cost.Fig. (6) showed the effect of forward speed on operational and criterion cost of treatments A and B at grain moisture content of $14.5 \%$ under different planting methods. 
Treatment A

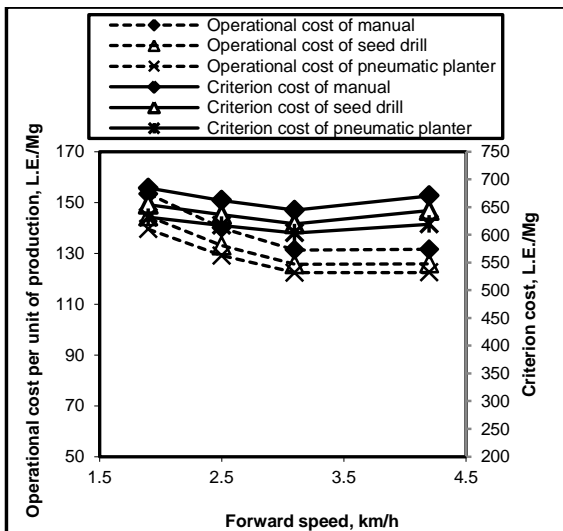

Treatment B

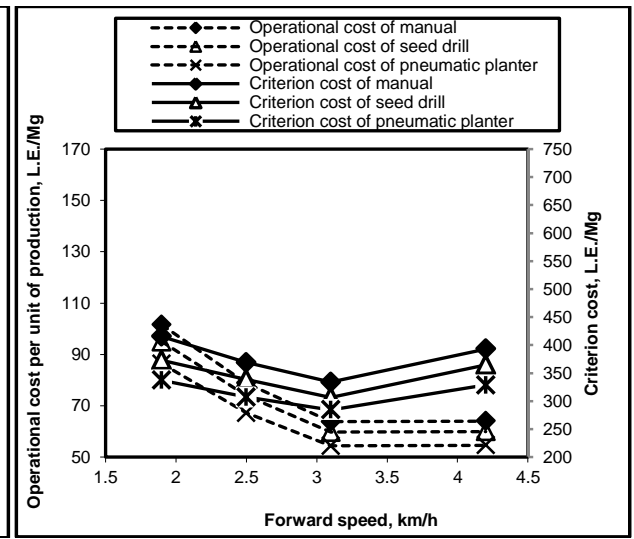

Fig. (6): Effect of forward speed on operational and criterion cost of treatment $A$ and $B$ at grain moisture content of $14.5 \%$ under different planting methods

Treatment A

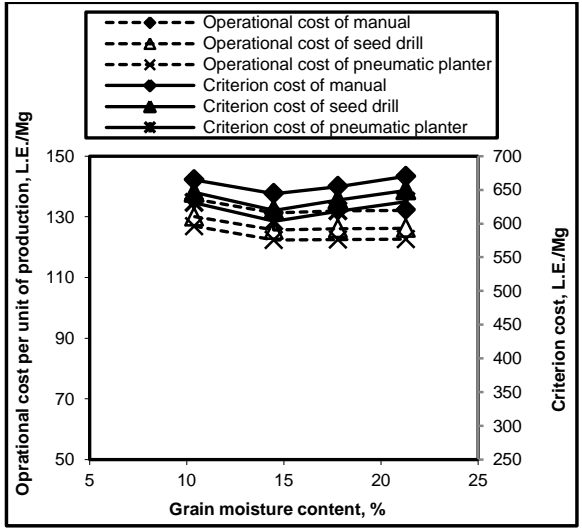

Treatment B

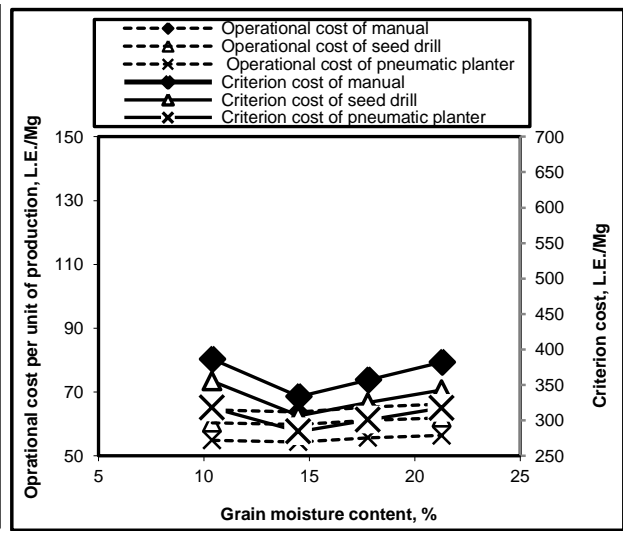

Fig. (7): Effect of grain moisture content on operational and criterion cost of treatment $A$ and $B$ at forward speed of $3.1 \mathrm{~km} / \mathrm{h}$ under different planting methods

Results explained that operational cost was decreased by increasing forward speed. This may be due to the increase in field capacity as forward speed increased. The decrease in operational cost was remarked up to $3.1 \mathrm{~km} / \mathrm{h}$ and then increased, because the rate of increase in fuel consumption was more than the increase in field capacity at forward speed of $4.2 \mathrm{~km} / \mathrm{h}$. The lowest value of operational cost was 131.29, 125.62 and 122.34 L.E./Mg for treatment $\mathrm{A}$ and 63.78, 59.75 and 54.35 L.E./Mg for treatment Bat forward speed of $3.1 \mathrm{~km} / \mathrm{h}$ and $14.5 \%$ grain 
moisture content under manual, seed drill and pneumatic planter methods, respectively. Whereas, the results clarified that the lowest criterion cost was 644.29, 619.62 and 603.34 L.E./Mg for treatment $\mathrm{A}$ and 333.78, 306.75 and 284.35 L.E./Mg for treatment $\mathrm{B}$ at the same former conditions. The highest value of whether operational or criterion costs were under manual methods. Because high density of plants caused more resistance to the machine, consumed more fuel and power and more losses were occurred. Concerning the effect of grain moisture content on operational and criterion cost of treatments $\mathrm{A}$ and Bat forward speed of $3.1 \mathrm{~km} / \mathrm{h}$ under different planting methodsis shown in Fig. (7), data obtained that the highest values of criterion cost were670.14, 649.21, 632.62 L.E./Mg for treatment A and 382.17, 342.91 and 317.35 L.E./Mg for treatment B at grain moisture content of $21.3 \%$ and forward speedof $3.1 \mathrm{~km} / \mathrm{h}$ under manual, seed drill and pneumatic planter, respectively. By increasing grain moisture content, the criterion cost was decreased up to $14.5 \%$ and then increased. This was attributed to the increase of high shattering, grain losses which occurred at high or low levels of moisture content. The main reason for the cost reduction under the use of treatment $\mathrm{B}$ (combine harvester) comparing with treatment $\mathrm{A}$ (reciprocating mower and thresher) was attributed to the fact that combine harvester was done multi-purposes functions of harvesting, threshing and winnowing in one pass, requiring minimumfuel as well as operational time, resulting in minimum operational cost, minimum losses and then, minimum criterion cost.

\section{CONCLUSION}

\section{Based on the obtained results in this study, the following recommendations can be drawn:}

1. Use treatment $B$ (combine harvester) gave the least total grain losses compared with treatment A(reciprocating mower and thresher).

2. Combine harvester recorded the least criterion cost comparing with using reciprocating mower and thresherunder forward speed of $3.1 \mathrm{~km} / \mathrm{h}$, grain moisture content of $14.5 \%$ and planting by pneumatic planter. 


\section{REFERENCES}

Awady, M. N. (1978). Engineering of tractors and agriculturalmachinery.Textbook, Col. Agric. Ain Shams Univ.: 174 p. (in Arabic).

Awady, M. N; E. Y. Ghoneim and A. I. Hashish (1982). A critical comparison between combine harvesters under Egyptian conditions. Res. But. No. 1920. Col. Agric. Ain Shams Univ.: P.13.

Barger, E. L; J. B. Liljedahl, W. M. Carleton and E. G. Mckibben (1963).Tractor and their power units. Wiley Eastern Private Limited, New Delhi, Second Edition.

El-Haddad, Z. A; M. Y. El-Anssary and S. A. Ali (1995): Cost benefit study under integrated mechanization systems. Misr J. Agric. Eng., 12 (1): 27-35.

Imara Z. M.;Kh. A. A. Khadr, W. M. Mechail and A. O. M. Arif (2003). Effect of different planting and harvesting methods on wheat production Misr J. Agr. Eng. 20(1):115-128.

Kepner, R. A.; R. Bainer and E. Barger (1978).Principles of farm machinery. Third Edition, AVI. publishing company, INC. Westport, Connecticut, U.S.A.

Lotfy, A; A. H. AmerEssa and G. R. Gamea (2002). A comparative study between two different methods for harvesting and threshing of winter rapeseed crop. Misr J. Agric. Eng., 19 (4): 867 - 880.

Mani, Z. Chun-Lie, L. I. Jun, Z. Ming-hai, C. Yu- gui, L. I. Guangming and Z. Shu-jie (2012). Mechanical Harvesting Effects on Grainyield loss, quality traits and profitability of winter oilseed rape(Brassica napus L.). J. of Integrative Agric., 11 (8): $1297-1304$.

الملخص العربي الكبو

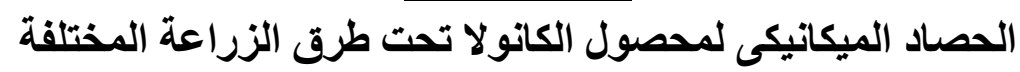

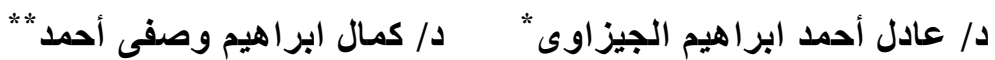

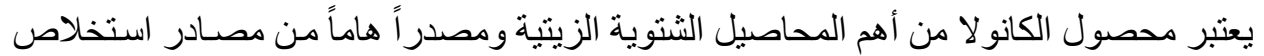

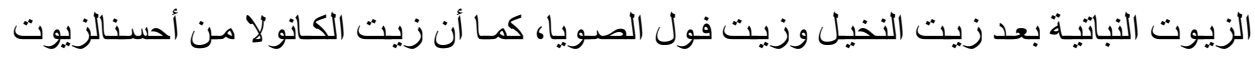
النباتية عند استخدامه في تغذية الإنسان.

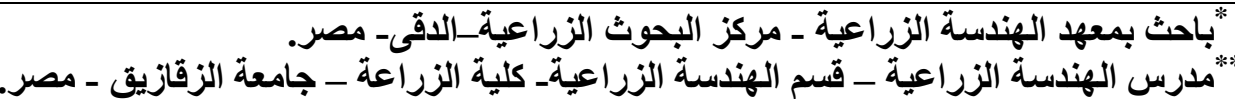




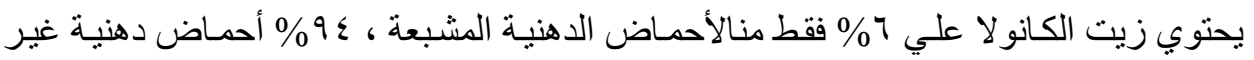

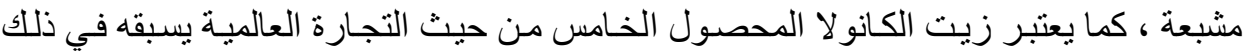

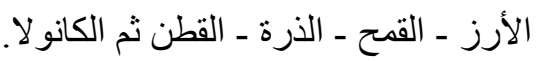
تهدف هذه الدراسة الى التوصية بالطريقه المثلى للحصاد الميكانيكى لمحصول الكانو لا مـن خـلال

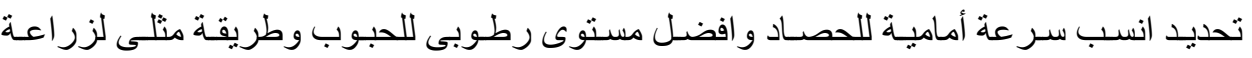

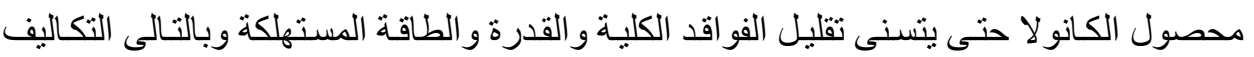
اللازمة لعملية الحصاد.

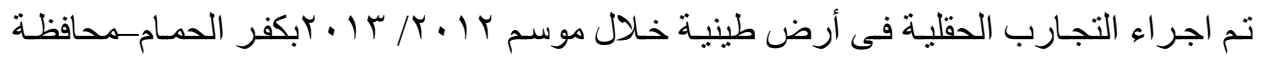
الثرقية وذللك فى مساحة قدر ها ثلاثة أفدنة تم زر اعتهم بمحصول الكانو لا وتم تقسيم الثلاتـة أفدنـة

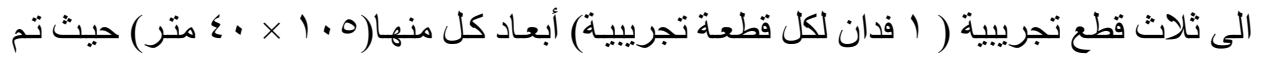

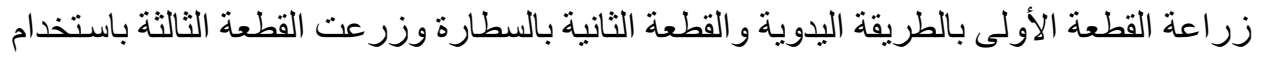

الزر اعة الاقيقة بالبلانتر. قسمت كل قطعة تجريبية الى قطعتين مساحة كل منها (نصف فدان). وقد أجريث التجربة باستخدام المعاملات الآتية:

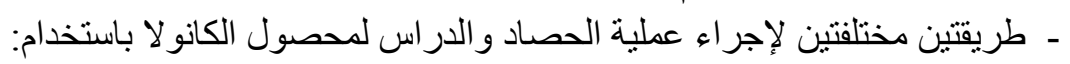

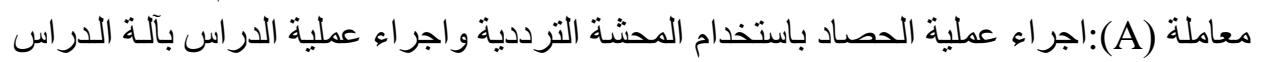
و التذرية الثابتة.

معاملة (B): استخدام الكومباين كنظام متكامل للحصاد و الدر اس و التذرية.

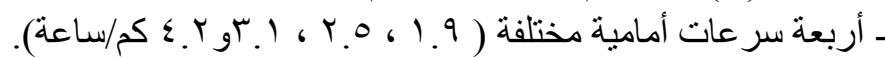

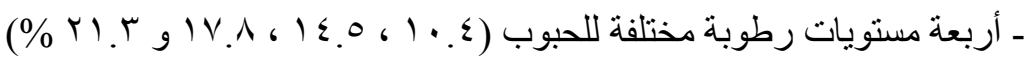

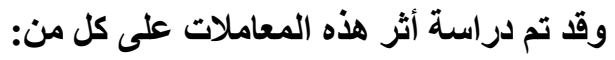

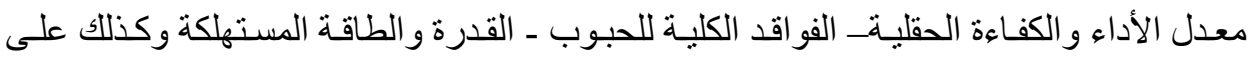
التكاليف الكلية المتطلبة لعملية الحصاد. ومن أهم النتائج المتحصل عليها يمكن التوصية بالآتى:

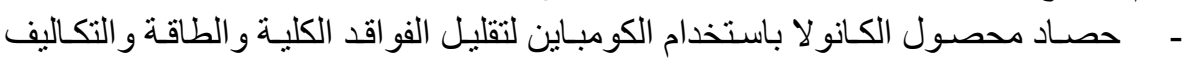
اللازمة وكذلك الوقت المستغرق فى عملية الحصاد.

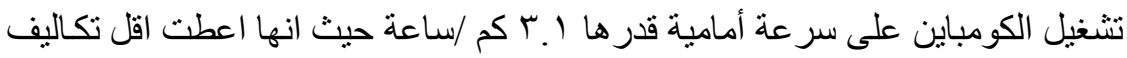
متطلبة لعملية الحصاد.

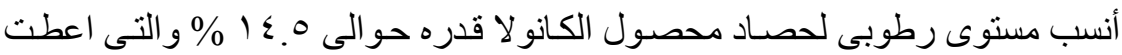
اقل فو اقد ممكنة.

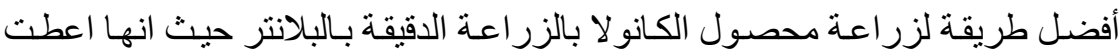

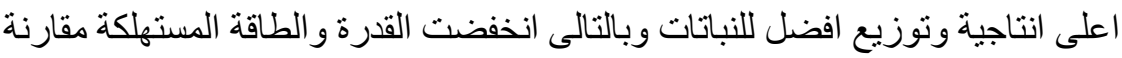

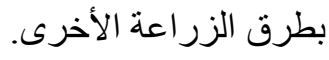

